\title{
Recruitment and Selection of Head Department (In West Java Province's Government of Indonesia)
}

\author{
Welasari $^{*}$, Utang Suwaryo ${ }^{2,}$ Leo Agustino ${ }^{2}$ and Affan Sulaeman ${ }^{2}$ \\ 1Padjadjaran University Bandung West Java / LPDP BUDI DN, Indonesia \\ ¿Padjadjaran University Bandung West Java, Indonesia
}

\begin{abstract}
This article reviews research on Recruitment and Selection of the Head of Department (in West Java Province's Government of Indonesia). This article shows the topic related to recruitment and selection of heads of departments in the staffing of the regional government of West Java Province. Indonesian Government Management of State Civil Service explains that the State Civil Service (ASN) policies and management are based on qualifications, competencies, and performance are fair and reasonable regardless of political background, race, colour, origin, gender, marital status, age or disability condition. The policy of filling in the High Leadership Position (JPT) through open selection has been widely implemented, to obtain state civil apparatus that have good qualifications, competencies and performance as a condition for occupying certain positions. This research uses taken mixed methodology instead of and takes the theory of merit systems and Government Regulation Management of Civil Servants. Opportunities for Civil Servants women to participate in the selection of Structural Position, where these terms are the recruitment of a merit system, which provides opportunities to candidates from internal and external organizations, organizational goals for getting competent employees can be implemented. Recruitment and Selection of the Head Department. The results showed that the recruitment was well carried out and made several changes in a positive direction including elected officials, minimizing the direct engagement made by regional heads, and concluded with this recruitment and selection research can be continued in the future. although slow and sometimes complicated, the general method used is open selection is meritocratic.
\end{abstract}

Keywords: Government, Recruitment, Open Selection.

\section{Introduction}

Research in the field of employee recruitment, selection and evaluation is one of the research domains. The research field of work and organization into the right practice interesting to study (Nikolaou, 2015), strengthened by studies from Ryan and Ployhart claiming that research on employee selection has been going on for a long time, but this field is still full of controversy. One of them illustrates recruitment and selection research based on seniority based on age. Currently, countries are applying merit-based recruitment methods to reduce injustice and to get a clean bureaucracy and good governance. Good governance also relies on state bureaucracy that with recruitment based on merit, then, the condition of supports to reduce behavioural corrupt countries in Asia western, Eropa tends to be closer to meritocracy than countries in southeast Asia (Dahlström, Lapuente, \& Teorell, 2012)(Dahlström, Lapuente, \& Teorell, 2012). That achievement-based recruitment generally provides benefits in public governance. Some literature on bureaucratic recruitment points to deviations, on the other hand, meritocracy provides the right balance in terms of social, ethnic or gender (Meier $\mathrm{KJ}$ and Capers KJ, 2012). The tension between meritocracy and democracy also arises when the educated people who dominate the political place (Bovens M and Wille A, 2009) the recruitment process is also influenced by the culture of state administration. Meritocratic administration, merit-based recruitment may come under pressure (see, Verheijen, 2012: 599). Indonesia is a country that implements a career merit system for civil servants based on Government Regulation No. 11 of 2017 concerning Management of State Civil Servants. Based on Law Number 5 the Year 2014 concerning State Civil Apparatus. In regulation, explained that the System of Merit is policy- late in management civil servant (ASN) which is based on qualifications, 
competence, and performance in a fair and reasonable without distinction of political background, race, colour, origin, gender.The Indonesian government is divided into central and regional governments. West Java province is a local government that has implemented an open bidding system in the recruitment and selection for bureaucratic officials namely High Position. The open bidding system provides opportunities for every participant who has fulfilled the qualifications and competencies to take part in the open selection process. This recruitment system is intended for echelon II publicly announced positions intending to minimize the occurrence of nepotism, collusion, and being able to produce the right people in structural positions (people who are in the right place).Recruitment by open selection for civil servants, for the prevention of patronage. Open selection based on performance and competitive exams. This agreement, although slow and sometimes complicated, the general method used is open selection is meritocratic. The staffing data in West Java's province can be seen from the following data.

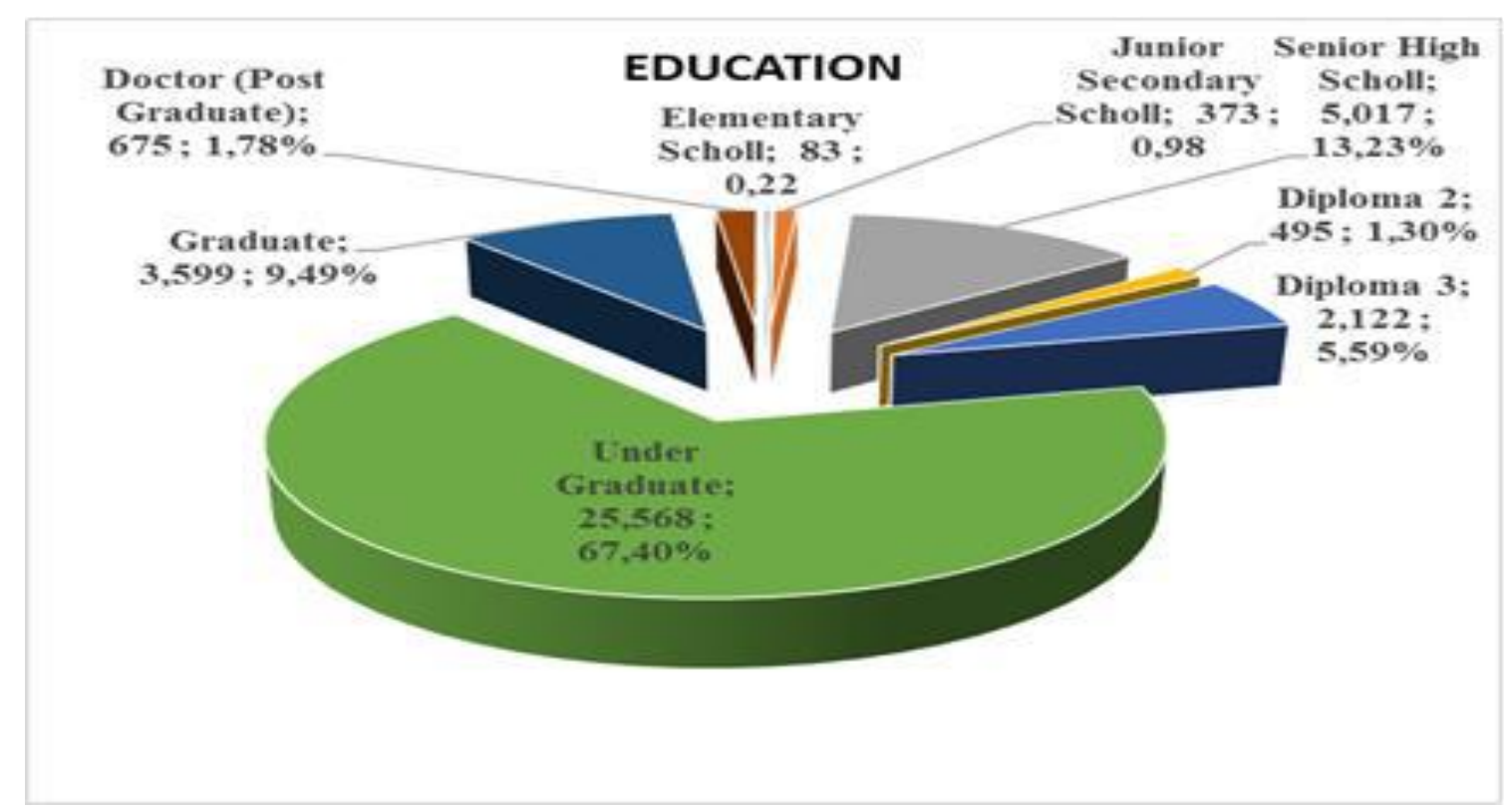

Figure 1 Based on Gender The data available as of September 2018 The number of Civil Servants (PNS) in West Java Province was 37,932 people consisting of 20,926 people or 55\% were male and 17,004 or 45\% were female. With the proportion of the number of civil servants who are almost balanced, they should be at the level of high leadership position also in an almost balanced proportion, so that the policies that will be produced will give a new color to local governments 


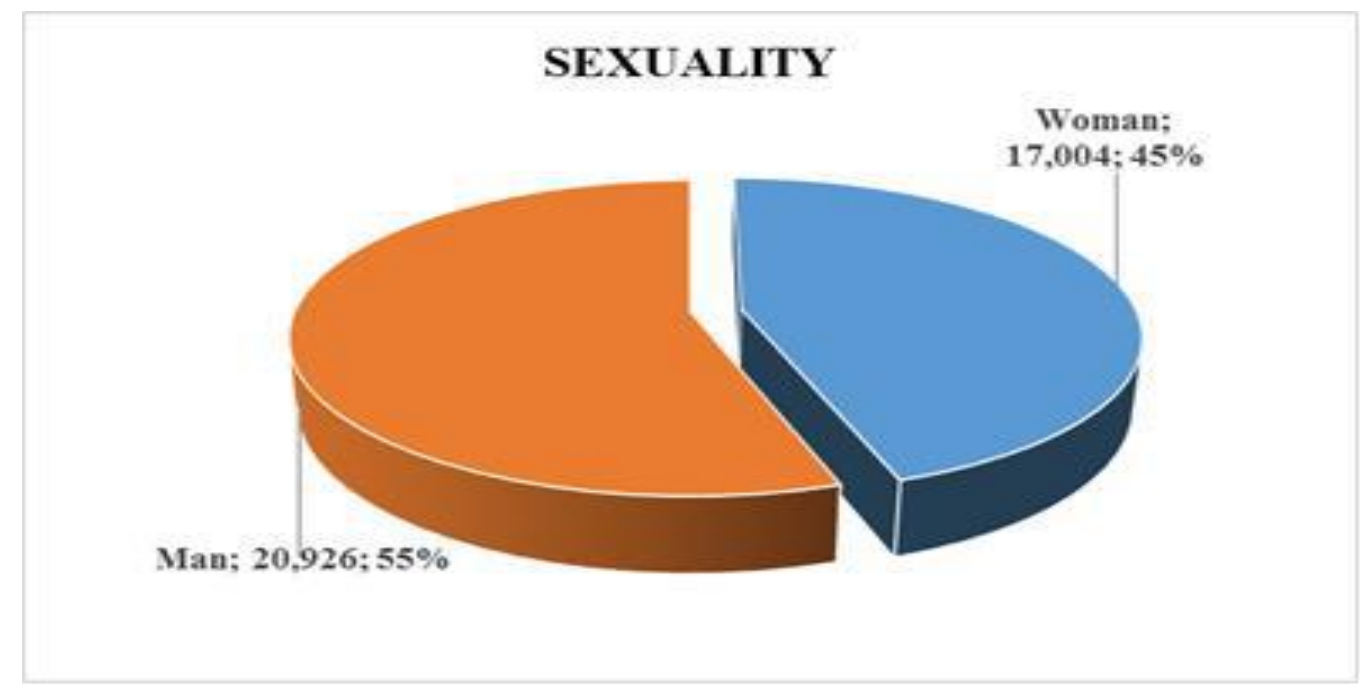

Figure 2 From the data it can be seen that the level of Education in the figure above shows that the majority of Education is dominated by Under Graduates by 25,568 people or 67.40\%, followed by Senior High School Levels of 5017 people or $13.32 \%$. Diploma III education is 2122 people or $5.59 \%$, Diploma II education is 495 people or 1.30\%, whereas for Elementary Scholl or Junior Secondary Scholl education is almost non-existent and only under 1\%. Graduate (Masters) of 3599 people or $9.49 \%$. While for education at the doctoral level only 675 people or $1.78 \%$.

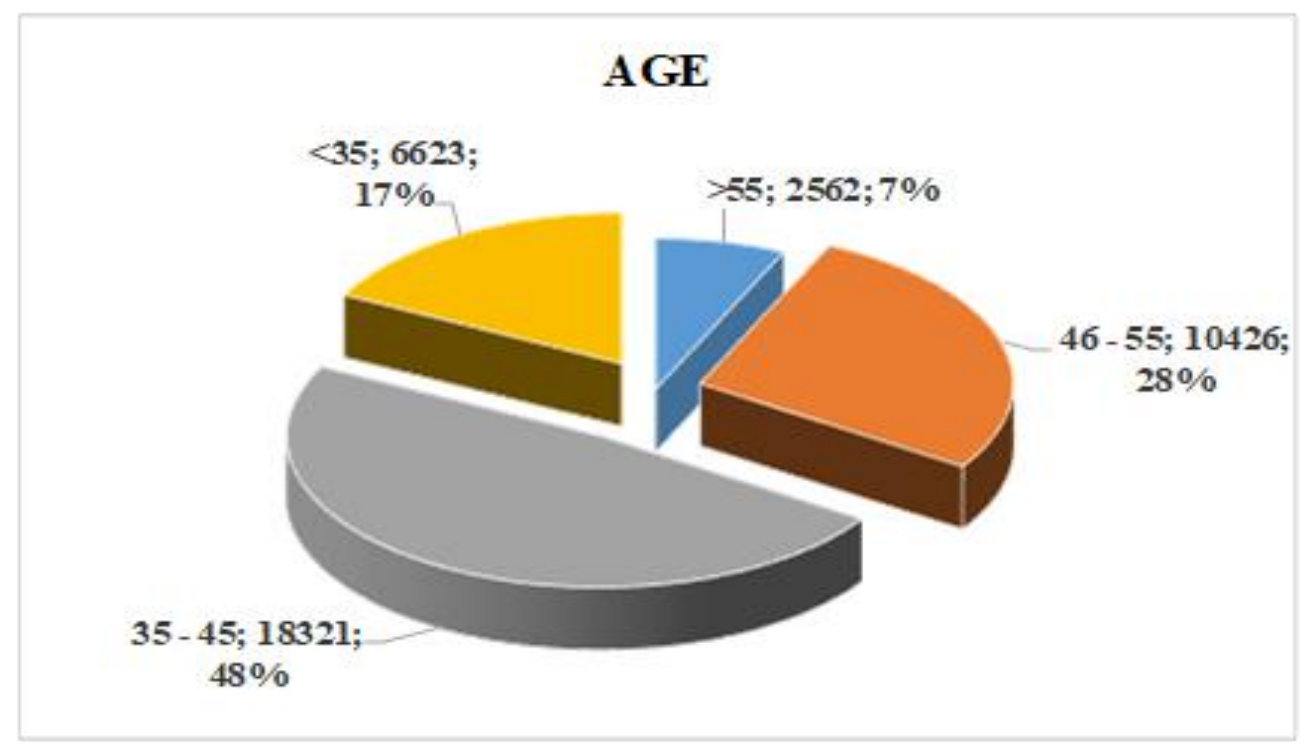

Figure 3 Explaining the productive age can affect performance. The data above shows that ages 35 to 45 years dominated, namely around 18,321 people or 48\%, and ages 46 to 55 years amounted to 10,426 people or 28\%, thus providing opportunities for a career and having a high level of work productivity. Ages over 55 are 2562 people or $7 \%$, while those less than 35 years are 6623 people or $17 \%$. 


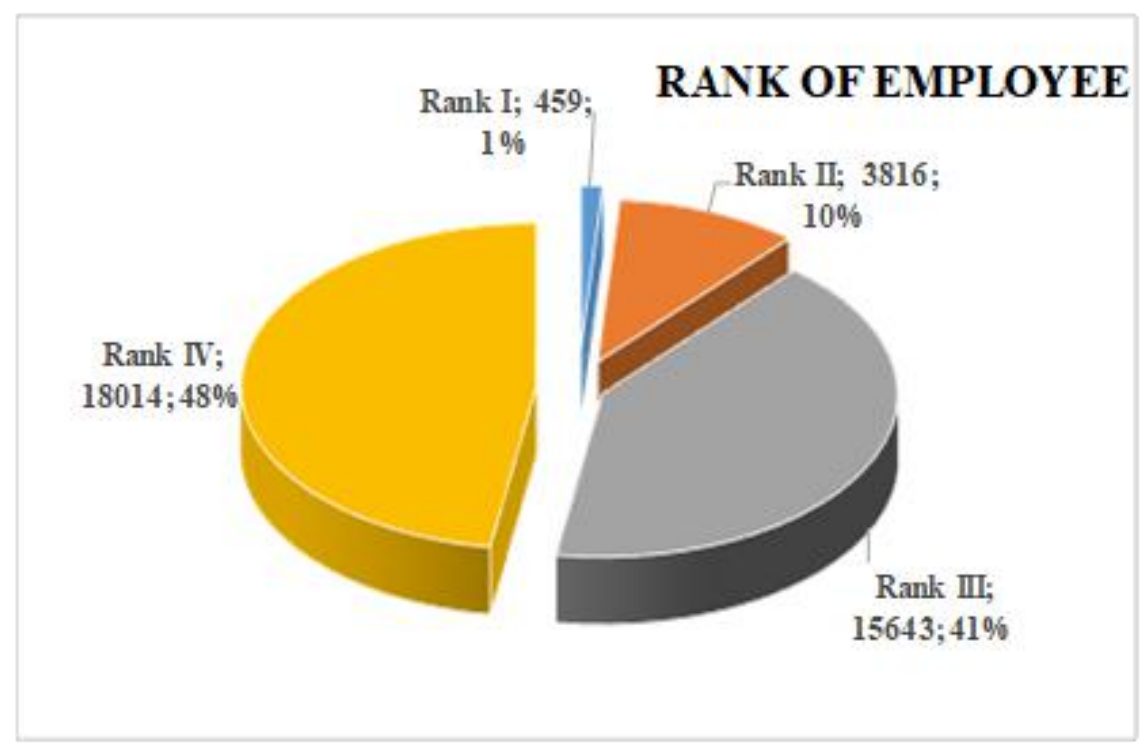

Figure 4 From the pie chart above we can see that group IV was 18,014 people or 48 percent, group III was 15,643 or 41 percent, group II was 3816 or 10 percent and the group I was 459 people or 1 percent. Group IV is the highest class in rank. This group is dominated in rank in the West Java Provincial Government because it was occupied by $48 \%$ of the total employees. This is a good signal for good governance.

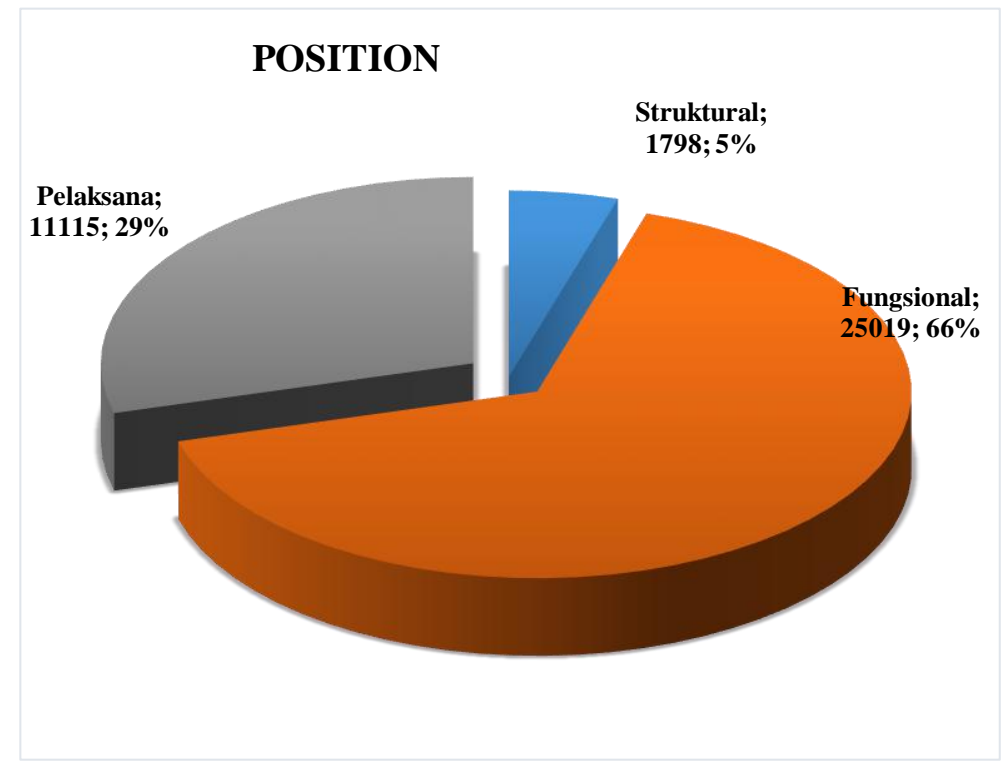

Figure 5 Civil Servants are appointed in certain positions and ranks. Civil Servants in a position carried out based on the principles of professionalism by competencies, work performance, and rank levels set for the position and other objective requirements without distinguishing gender, ethnicity, religion, race, and class. Career positions are structural and functional positions that can only be occupied by Civil Servants. To be appointed to a structural position, a Civil Servant must meet certain requirements. data of people occupying structural positions totaled 1,798 people or $4.74 \%$, functional positions 25,019 people or $65.96 \%$ and those who held executive positions were 11,115 people or $29.30 \%$.

In mid-year 2018 at the beginning of the leadership of Governor Ridwan Kamil conducted an open bidding process for several vacant positions. Through the inauguration, in the career process ASN and the rules and competencies. So the process is relatively long, from November 2018 to February 2019. The 14 echelon officials by selection of, namely the Head of the Office of Communication and Information, the Head of the Energy and Mineral Resources Office, the Head of the Youth and Sports Service, the Head of the Highways and 
Spatial Planning Office, the Head of the Water Resources Office, the Head of the Office of Energy Work and Transmigration, Head of Cooperative and Small Business Service Office, Head of Village Community Empowerment Office, Head of Transportation Office, Head of Legal and Human Rights Bureau of the Regional Secretariat, Head of the Service and Social Development Bureau of the Regional Secretariat, Head of the Public Relations and Protocol Bureau of the Regional Secretariat, Head of the Bureau General of the Regional Secretariat and the Head of the Procurement of Goods and Services of the Regional Secretariat. Ridwan said, 14 officials who would help with this task consisted of ten men and four women. They dominated by the internal West Java Provincial Government. strategic steps to restore the quality of ASN in Indonesia by improving the ASN electoral system which is preferred in a meritocracy. The priority ASN selection system for High Officials is carried out in the right way. But until now, the selection of high positions both Pratama there are still some obstacles. The rules for filling the High Leadership Position are through the process of the inauguration and job fit (conformity test). If the two mechanisms have not produced a suitable civil servant to occupy a high-level vacant leadership position, an open and competitive selection must be held. It should be noted together that in a selection system that is not based on a merit system (non-merit based system), then what applies is the practice of likes and dislikes (likes and dislikes) in dismissal from a high leadership position. Under these conditions, filling high positions will not be based on the best achievements or the best abilities, but on friendship, family relationships, and political relations.

To follow up on the ASN Law, Government Regulation Number 11 of 2017 concerning Management of Civil Servants was issued. High Leadership Position (JPT) as stipulated in the ASN Law is an ASN employee who occupies a High Leadership Position (JPT). The requirements for civil servants to be appointed in order to occupy a structural position (Administrator to JPT) one of which must have qualifications and education levels that have been determined, because in essence qualifications and education level will support the implementation of internal tasks his position professionally, especially the application of theoretical frameworks, methodological analysis the implementation of duties in his position. Technically, in Regulation Number 11 of 2017 echelon II in the area (JPT Pratama) regulated in article 107 letter regulates the requirements for filling positions are:

1. Having the lowest educational qualifications of a bachelor or diploma IV;

2. Having technical competence, advanced competence, and social competence cultural according to the standard competency set;

3. Has experience of office in the field of duties related to positions to be cumulatively occupied for at least 5

(five years;

4. Being or never occupying the position of administrator or $\mathrm{F}$ expert level intermediate for a minimum of 2 (two) years;

5. Has a good track record of position, integrity and morality;

6. The highest age is 56 (fifty-six) years; and

7. Physically and mentally healthy.

In addition to providing the above conditions, filling JPT Pratama in the area is carried out is open to all qualified Civil Servants.

Step by step on selection open 
1. Notification to the Ministry Of Administrative And Bureaucratic Reform and commission Of State Civil Apparatus

2. Formation of the Selection Committee

3. Compilation of Competency Standards

4. Selection Assessment Guidelines

5. Announcement of candidate selection

6. Administrative Selection

7. Announcement of Administrative Selection Results

8. Announcement of making papers

9. Announcement of paper test results

10. Announcement of interview test

11. Announcement of the results of the interview test

12. Test results and get 3 participants

13. Determination of selected candidates

Table 1 Primary High Leadership Position (Echelon II)

\begin{tabular}{lllll}
\hline $\begin{array}{l}\text { Rank, Cass, and } \\
\text { level }\end{array}$ & Old Position & New Position & Gender & Department \\
\hline $\begin{array}{l}\text { Level I coaches } \\
\text { (IV/b) }\end{array}$ & $\begin{array}{l}\text { Secretary of the Regional } \\
\text { Development Planning } \\
\text { Agency }\end{array}$ & $\begin{array}{l}\text { Head of the Department of } \\
\text { Energy and Mineral } \\
\text { Resources }\end{array}$ & Male & $\begin{array}{l}\text { Mineral Resources } \\
\text { Departmen }\end{array}$ \\
\hline $\begin{array}{l}\text { Level I coaches } \\
\text { (IV/b) }\end{array}$ & $\begin{array}{l}\text { Head of Cooperative } \\
\text { Empowerment and } \\
\text { Cooperatives and Small } \\
\text { Business Services }\end{array}$ & $\begin{array}{l}\text { Head of Cooperative and } \\
\text { Small Business Service }\end{array}$ & Male & $\begin{array}{l}\text { Department of } \\
\text { Cooperatives and } \\
\text { Small Business }\end{array}$ \\
\hline $\begin{array}{l}\text { Level I coaches } \\
\text { (IV/b) }\end{array}$ & $\begin{array}{l}\text { Secretary of the } \\
\text { Community and Village } \\
\text { Empowerment Office }\end{array}$ & $\begin{array}{l}\text { Head of the Department of } \\
\text { Transmigration }\end{array}$ & Male & $\begin{array}{l}\text { Department of } \\
\text { Manpower and } \\
\text { Transmigration }\end{array}$ \\
\hline $\begin{array}{l}\text { Level I coaches } \\
\text { (IV/b) }\end{array}$ & $\begin{array}{l}\text { Head of Bandung City } \\
\text { Planning, Development, } \\
\text { Research and }\end{array}$ & $\begin{array}{l}\text { Head of Transportation } \\
\text { Department }\end{array}$ & Male & $\begin{array}{l}\text { Transportation } \\
\text { Department }\end{array}$ \\
\hline $\begin{array}{l}\text { Pevelopment Agency } \\
\text { Yuilder (IV/c) }\end{array}$ & $\begin{array}{l}\text { General Functional } \\
\text { Development Planning } \\
\text { Agency }\end{array}$ & $\begin{array}{l}\text { Head of Highways and } \\
\text { Spatial Planning Office }\end{array}$ & Male & $\begin{array}{l}\text { Bina Marga Office } \\
\text { and Spatial }\end{array}$ \\
\hline $\begin{array}{l}\text { Level I coaches } \\
\text { (IV/b) }\end{array}$ & $\begin{array}{l}\text { Secretary of the Regional } \\
\text { Research and } \\
\text { Development Department }\end{array}$ & $\begin{array}{l}\text { Head of Water Resources } \\
\text { Agency }\end{array}$ & Female & Water Resources \\
\hline Level I coaches & $\begin{array}{l}\text { Secretary of the Human } \\
\text { Resources Development }\end{array}$ & Head of the Youth and & Male & Department \\
\hline
\end{tabular}




\begin{tabular}{|c|c|c|c|c|}
\hline (IV/b) & Department & Sports Service & & Youth and Sports \\
\hline $\begin{array}{l}\text { Young Main } \\
\text { Builder (IV/c) }\end{array}$ & $\begin{array}{l}\text { Head of the Women's } \\
\text { Empowerment Office for } \\
\text { Child Protection and } \\
\text { Community } \\
\text { Empowerment, Bandung } \\
\text { City Government }\end{array}$ & $\begin{array}{l}\text { Head of the Community } \\
\text { and Village Empowerment } \\
\text { Department }\end{array}$ & Male & $\begin{array}{l}\text { Community and } \\
\text { Village } \\
\text { Empowerment } \\
\text { Department }\end{array}$ \\
\hline $\begin{array}{l}\text { Level I coaches } \\
\text { (IV/b) }\end{array}$ & $\begin{array}{l}\text { Head of the Jakarta Smart } \\
\text { City Management Unit at } \\
\text { the Jakarta Provincial } \\
\text { Communication, } \\
\text { Information and Public } \\
\text { Relations Office }\end{array}$ & $\begin{array}{l}\text { Head of the Departmen of } \\
\text { Communication and } \\
\text { Information }\end{array}$ & Male & $\begin{array}{l}\text { Communication } \\
\text { and Information } \\
\text { Department }\end{array}$ \\
\hline $\begin{array}{l}\text { Level I coaches } \\
\text { (IV/b) }\end{array}$ & $\begin{array}{l}\text { Head of Welfare and } \\
\text { Discipline Division at the } \\
\text { Regional Personnel } \\
\text { Agency }\end{array}$ & $\begin{array}{l}\text { Head of the General Bureau } \\
\text { of the Regional Secretariat }\end{array}$ & Male & $\begin{array}{l}\text { Department of the } \\
\text { Regional } \\
\text { Secretariat }\end{array}$ \\
\hline $\begin{array}{l}\text { Level I coaches } \\
\text { (IV/b) }\end{array}$ & $\begin{array}{l}\text { Head of E-Government } \\
\text { Communication and } \\
\text { Information Department }\end{array}$ & $\begin{array}{l}\text { Head of Regional } \\
\text { Secretariat Procurement of } \\
\text { Goods / Services }\end{array}$ & Female & $\begin{array}{l}\text { Department of the } \\
\text { Regional } \\
\text { Secretariat }\end{array}$ \\
\hline $\begin{array}{l}\text { Level I coaches } \\
\text { (IV/b) }\end{array}$ & $\begin{array}{l}\text { Head of Cooperation } \\
\text { Section, Government and } \\
\text { Cooperation Bureau }\end{array}$ & $\begin{array}{l}\text { Head of the Legal and } \\
\text { Human Rights Bureau of } \\
\text { the Regional Secretariat }\end{array}$ & Female & $\begin{array}{l}\text { Department of the } \\
\text { Regional } \\
\text { Secretariat }\end{array}$ \\
\hline $\begin{array}{l}\text { Main } \\
\text { Counselors } \\
\text { (IV/d) }\end{array}$ & $\begin{array}{l}\text { Assistant for Economy and } \\
\text { Regional Secretariat } \\
\text { Development in South } \\
\text { Kalimantan Province }\end{array}$ & $\begin{array}{l}\text { Head of the Public } \\
\text { Relations Bureau and } \\
\text { Regional Secretariat } \\
\text { Protocol }\end{array}$ & Male & $\begin{array}{l}\text { Department of the } \\
\text { Regional } \\
\text { Secretariat }\end{array}$ \\
\hline $\begin{array}{l}\text { Level I coaches } \\
\text { (IV/b) }\end{array}$ & $\begin{array}{l}\text { Department of Social } \\
\text { Services Secretary }\end{array}$ & $\begin{array}{l}\text { Head of the Regional } \\
\text { Secretariat for Social } \\
\text { Services and Development }\end{array}$ & Female & $\begin{array}{l}\text { Department of the } \\
\text { Regional } \\
\text { Secretariat }\end{array}$ \\
\hline
\end{tabular}

From these data, it can be seen from the fourteen (14) open positions that are still dominated by men, namely $71.43 \%$ and the remaining $28.57 \%$ positions are filled by women. From the data and the problems above.

The focus of this research is the recruitment and selection of positions of the head of the department based on the merit system without differentiating gender status. The recruitment of civil servants in the West Java Provincial Government when recruiting as structural officials have a balanced proportion and there is no difference. Recruitment by open selection for civil servants, for the prevention of patronage. Open selection based on performance and competitive exams. This agreement, although slow and sometimes complicated, the general method used is open selection is meritocratic. Civil servants who are recruited and promoted due to their skills and merits rather than on patronage political party affiliation, friendship or kinship tend to embrace values of integrity more than others (Pedersen KH and Johannsen, 2015).

The Research used mixed methodology instead of a and takes the theory of merit systems and Government Regulation Management of Civil Servants, The leading monist alternative in the social sciences holds that qualitative methodology is based on principles of statistical methodology (King, G., Keohane, R., 1994) Qualitative research may have its own vocabulary and methods, but it "has no inferential machinery distinct from that of quantitative. Government regulation number 5 of 2014 concerning state civil Aparatur (ASN) and defines the principle of merit as follows:

a. Jobs at every level: the principle of merit must be applied not only for promotion, however also for initial recruitment; 
b. The best candidate: Choose the best from a number of candidates, someone who is considered able to carry out their duties properly;

c. Open to all: Recruitment must be open, not limited to from internal agencies or from limited groups;

d. Systematic, transparent and challengeable: The recruitment process must be systematic, transparent and competitive, where complaints from failed candidates are considered valuable input that will improve the quality of future decisions.(United Nation Development Programme, 2015)

\section{Results and concluding}

Government policies regarding the Appointment of Civil Servants in Structural positions as stipulated in among others, state that a person who is appointed to a structural position must have good work performance and meet the required office competency requirements. Regional civil service supervisors need to pay attention to factors in the appointment of civil servants in structural positions including:

1. Seniority

2. Age. In determining the priorities and aspects of age one must consider factors of development and broader opportunities for civil servants to carry out structural positions.

3. Position of Education and Training (Diklat).

4. Job Experience.

opportunities and access for female PNS to fill structural positions are in principle the same as opportunities for male PNS. Competition to fill structural positions, ideally male and civil servants. Women's civil servants are based on competence and qualifications not based on proximity and must compete fairly. Therefore, so those female civil servants can win this competition not only requires managerial and leadership needs but also the skills demonstrated by women in leading. Several factors cause the number of female civil servants who occupy structural positions to be smaller. The factor is more because the number of female civil servants is still not comparable to the number of male civil servants, limitations in the competency of a female civil servant. Even though the terms of the requirements are not differentiated, if the relevant PNS does not have the ability, the PNS will not be submitted to become a structural official/register to participate in the open selection / open biding to be able to fill strategic positions. in recruiting a civil servant to fill a structural position, it does not distinguish between sexes but depends on how much the capacity and competence of the civil servant is concerned, the number and quality of female civil servants need to be improved so that there is no difference in access between male and female civil servants in occupying structural positions. Competence has multiple functions that are useful as a reference in the selection (selection/recruitment), compensation (compensation), observation/training (observation/coaching), performance appraisal, assessment of educational and organizational needs (organizational alignment), career planning (career planning), succession planning, and promotion/placement. The implementation of competitive open selection and referring to the merit-based on the system will provide results that are in line with what is expected by the government so far, namely one employee who has the competency to be able to occupy certain structural positions. With the existence of employees who have competence at least, you can have a significant positive impact on the running of the bureaucracy and the quality of the agency.

recruitment was well Carried out and made Several changes in a positive direction Including Elected Officials, minimizing the direct engagement made by the regional heads, and concluded with this recruitment and selection of research can be continued in the future. Decision making is very important because it is the basis for implementing policies that have been formulated by the Regional Government. For this reason, the existence of this balanced percentage between men and women in high leadership positions is a positive signal, especially in capturing responses from the gender category. We know that in making decisions man tends to use logic to think based on reality in the field by taking material from the results of meetings, interviews, and field monitoring. While women also use the logic of thinking that is based on reality and also taking the same material, but there is a tendency that decision making is based on women's intuition and perspective from different sides such as humanity and friendliness. If seen from the data on the number of civil servants in West Java Province as the 
following data as outlined in Figure 2 shows the data about Education owned by West Java Province employees. Working-age is still productive between the ages of 35 to 45 years of 18,321 or $48 \%$ who still have the opportunity to develop their employment careers that can. From figure-figure on the side, we can see that highly educated civil servants have reached very satisfying levels because more than 50 percent have attained strata level 1 education. This is a positive symbol because with the increasing number of highly educated human resources, the way they work is good conceptually and at an implementation level that will certainly become more structured and directed. The level of their intelligence is also not to be doubted because with such highly educated they are customized to face various material problems especially those related to services and administration. They certainly have a way of identifying and preparing problems-solving to overcome work problems. Very different from the local government whose majority education is still the majority are not scholars. In dealing with situations it will certainly be a little different. Someone highly educated tends to be wiser in terms of applying the rules and how to convey them. The means by which governments select bureaucratic officials are likely to be closely associated with the performance of state bureaucracies. Meritbased recruitment may yield more productive officials than other methods of selection. The term open position selection refers to the method of appointment or filling of structural positions in government, both central and regional through an open promotion system. The office auction is believed to be the biggest lever of bureaucratic change. In addition to fostering fair, objective, and free competition, open promotion through position auctions is carried out transparently, using indicators that have been determined and carried out by parties who are neutral and are competent to make a selection. At present, this model is believed to be the most appropriate means to forget the best candidates for leadership or officials. With the ASN (State Civil Apparatus) Act, the government stipulates that the process of recruiting public positions is carried out through the Merit System, namely recruitment based on qualifications, competencies, and performance fairly and fairly without differentiating between political backgrounds, race, skin colour, religion, origin proposal, sex, marital status, age or disability condition. Indeed, the ASN Law is a milestone in the improvement of ASN career management which is carried out fairly and fairly.

Barriers that arise when the career pattern of civil servants who require them to undergo mutation in a position as a promotional pathway, then they have many considerations, namely family. Civil servant women certainly have a dual role in carrying out their profession as civil servants. On the one hand, he must have a career but on the other hand, he must also take care of her husband and children. That is why they can not be total in a career. Sometimes they have limited themselves to certain positions or echelons only because they are worried that when their echelon is getting higher, there will be less time with family. It is very well understood when the position of female civil servant echelons is higher, especially until the Primary Leadership Position (Echelon II), then it has demanded for longer and inflexible working hours so that there are obstacles in the division of time between work and family time. As a result, women prefer family over career. This kind of thing rarely happens to male civil servants. This promotion pattern is an invisible obstacle for female civil servants and is not detected by regulations based on a merit system such as the State Civil Apparatus Act (ASN) as a legal basis for civil servants. Existing recruitment and promotion policies at the moment put forward the relocation and neglect of the reality of the gap between female civil servants and male civil servants. There are several obstacles or challenges faced by women who become civil servants. These constraints are a culture in the work environment where the role of men is still considered dominant and as if they are considered leaders for women. The next obstacle is the mandatory role of a housewife who takes care of all the needs of her husband. Another obstacle is the lack of work environment support for careers and tends to make women as additional strength and as if not a major force, especially those who do not have positions. The role of civil servant women is very important. Without prejudice to her nature as a housewife who takes care of her husband, female civil servants and male civil servants must be aligned in steps to create an advanced regional government. In Sundanese culture, of course, women are very delicate, said and polite in serving. This has become a basic capital for local governments to continue to develop. Advances in information and communication technology and the 
development of science demand changes in the government bureaucracy and keep abreast of the dynamics and demands of society. To realize this, it must start from the structuring and management of.

\section{Acknowledgements}

This research was financially supported by the Education Fund Management Institutions (LPDP). Ministry of Finance, Ministry of Research, Technology and Higher Education and Excellence Scholarship of Indonesia Lecturer-Domestic (Budi-DN).

\section{References}

Bovens M and Wille A. (2009). Diploma Democracy. On the Tensions between Meritocracy and Democracy (Utrecht/Le). BovensMand Wille A (2009) Diploma Democracy. On the Tensions between Meritocracy and the Netherlands: NWO programme Contested Democracies.

Dahlström, C., Lapuente, V., \& Teorell, J. (2012). The Merit of Meritocratization: Politics, Bureaucracy, And The Institutional Deterrents of Corruption. Political Research Quarterly, 65(3), 656-668. https

King, G., Keohane, R., and V. (1994). Designing social inquiry: scientific inference in qualitative research. Princeton, NJ: Princeton University Press.

Meier KJ and Capers KJ. (2012). Representative bureaucracy: Four questions. In: Peters BG and Pierre J (eds) (Handbook o). London: Sage.

Nikolaou, I. (2015). Employee Recruitment, Selection, and Assessment. In A. B. Bakker (Ed.), Employee Recruitment, Selection, and Assessment.

Pedersen KH and Johannsen. (2015). European values and practices in post-communist public administration: The Baltic states. In: Sager F and Overeem P (eds) The European Public Servant. A Shared Administrative Identity? Colchester: ECPR Press.

United Nation Development Programme. (2015). Meritocracy for Public Service. Excellence. Singapore: UNDP Global Centre for Public Service Excellence. 